\title{
Synthesis of Isonitriles from N-Substituted Formamides Using Triphenylphosphine and lodine
}

\author{
Xia Wang \\ Qing-Gang Wang \\ Qun-Li Luo*
}

Key Laboratory of Applied Chemistry of Chongqing Municipality, College of Chemistry and Chemical Engineering, Southwest

University, Chongqing 400715, P. R. of China

qlluo@swu.edu.cn

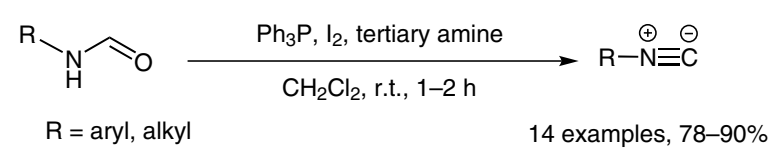

formamides using acyl halides of group IV-VI elements in the presence of a base as the dehydrating agent. ${ }^{5 a}$ Among these dehydrating reagents, acyl halides of group IV elements, typically, phosgene and its related compounds, are particularly efficacious, but their application is limited due to their extreme toxicity and/or high costs. ${ }^{6}$ At the same time, sulfonyl chlorides (which are acyl halides of group VI elements) with low toxicity, are also efficient dehydrating reagents in the presence of bases for the preparation of isocyanides from formamides, but these reagents are mainly used for the dehydration of $\mathrm{N}$-alkyl-substituted formamides rather than the $\mathrm{N}$-aryl-substituted counterparts. ${ }^{7}$ Consequently, a system utilizing phosphoryl trichloride and an organic base is most commonly used. ${ }^{3 \mathrm{c}}$ However, phosphoryl trichloride is a specific controlled hazardous substance under a series of legal regulations in China ${ }^{8}$ and Japan. ${ }^{9}$ For ordinary users in China, to obtain such reagents requires a purchase license for highly toxic chemicals issued by the local public security bureau. Therefore, efficient methods for the preparation of isocyanides employing readily accessible and cheap dehydrating reagents with low toxicity are attractive. ${ }^{9,10}$ In our previous research, ${ }^{11}$ we found that $\mathrm{N}, \mathrm{N}$ dimethylformamide (DMF) was not suitable for the amidation of carboxylic acids promoted by trimethyl phosphite and iodine, whereas $\mathrm{N}$-methyl-2-pyrrolidone (NMP) gave good results. During further examination of this observation, we found that the combination of triphenylphosphine and iodine was an efficient dehydrating system toward formamides, which could be used for the preparation of isocyanides under ambient conditions. This finding has led to the development of a practical method for convenient access to isonitriles by using inexpensive and readily available reagents of low toxicity.

We began our studies on the dehydration of formamides by using the combination of trimethyl phosphite and iodine (Table 1). It was disclosed in previous research ${ }^{11}$ that the in 
Table 1 Dehydration of Formamides Promoted by Phosphorus(III) Compounds ${ }^{\mathrm{a}}$

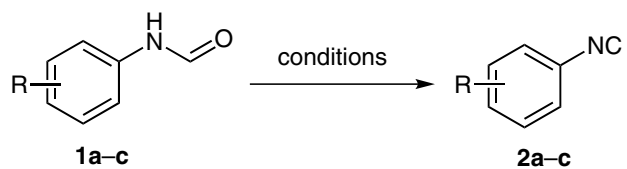

\begin{tabular}{|c|c|c|c|}
\hline Entry & $\mathrm{R}$ & Conditions $^{\mathrm{b}}$ & Results \\
\hline $1^{\mathrm{c}}$ & $4-\mathrm{MeO}$ & $1 \mathbf{a} / \mathrm{P}(\mathrm{OMe})_{3} / \mathrm{I}_{2} / \mathrm{Et}_{3} \mathrm{~N}=1: 4.5: 4.5: 13.5$ (added in portions), ice-bath to r.t., $4 \mathrm{~h}$ & $60 \%$ d \\
\hline 2 & 4-MeO & $\mathbf{1 a} / \mathrm{P}(\mathrm{OMe})_{3} / \mathrm{I}_{2} / \mathrm{DIPA}=1: 3: 3: 9$ (added in portions), ice-bath to r.t., $4 \mathrm{~h}$ & partial conversion $^{\mathrm{e}}$ \\
\hline 3 & 4-MeO & $1 \mathbf{a} / \mathrm{P}(\mathrm{OEt})_{3} / \mathrm{I}_{2} / \mathrm{DIPEA}=1: 2: 2: 6$, ice-bath to r.t., $2 \mathrm{~h}$ & partial conversion ${ }^{\mathrm{e}}$ \\
\hline 4 & $4-\mathrm{Br}$ & $\mathbf{1 b} / \mathrm{P}(\mathrm{OMe})_{3} / \mathrm{I}_{2} / \mathrm{DIPEA}=1: 2: 2: 6$, ice-bath to $30^{\circ} \mathrm{C}, 24 \mathrm{~h}$ & partial conversion $^{\mathrm{e}}$ \\
\hline 5 & 4-MeO & $1 \mathrm{a} / \mathrm{P}(\mathrm{OMe})_{3} / \mathrm{I}_{2} / \mathrm{DMAP}=1: 2: 2: 6$, ice-bath to r.t., $2.5 \mathrm{~h}$ & no reaction ${ }^{e}$ \\
\hline 6 & $2-\mathrm{O}_{2} \mathrm{~N}$ & $1 \mathrm{c} / \mathrm{P}(\mathrm{OMe})_{3} / \mathrm{I}_{2} / \mathrm{Et}_{3} \mathrm{~N}=1: 2: 2: 6$, ice-bath to r.t., $12 \mathrm{~h}$ & no reaction ${ }^{e}$ \\
\hline $7^{c}$ & 4-MeO & $1 \mathbf{a} / \mathrm{Ph}_{3} \mathrm{P} / \mathrm{I}_{2} / \mathrm{Et}_{3} \mathrm{~N}=1: 1.5: 1.5: 3$, r.t., $1 \mathrm{~h}$ & $90 \%^{d}$ \\
\hline
\end{tabular}

a Formamide 1 (0.1 mmol) was used unless otherwise stated.

${ }^{\mathrm{b}}$ DIPA = diisopropylamine; DIPEA = N,N-diisopropylethylamine; DMAP = 4-(N,N-dimethylamino)pyridine.

c Formamide 1 a (1 mmol) was used.

d Yield of isolated product.

e Monitored by thin-layer chromatography (TLC).

situ reaction of trialkyl phosphites and iodine formed alkyl iodophosphates, which were efficient activating reagents for the carboxyl group. However, the carboxyl activation did not occur in $\mathrm{N}, \mathrm{N}$-dimethylformamide, whereas $\mathrm{N}$-methyl-2pyrrolidone and other common organic solvents gave good results. ${ }^{11}$ We deduced that the deactivation of iodophosphates in $\mathrm{N}, \mathrm{N}$-dimethylformamide resulted from the reaction of the iodophosphate with the formamide. In addition, chlorophosphate compounds are known to be efficient reagents for the dehydration of formamides. ${ }^{9}$ Thus, we hoped that the combination of trimethyl phosphite and iodine could be used as a dehydrating system for the preparation of isonitriles. When $\mathrm{N}$-(4-methoxyphenyl)formamide (1a, $\mathrm{R}=\mathrm{OMe}$ ) or $\mathrm{N}$-(4-bromophenyl)formamide $(\mathbf{1} \mathbf{b}, \mathrm{R}=\mathrm{Br})$ was employed as the substrate, the dehydration took place (Table 1 , entries $1-4$ ), but the conversions were incomplete, even with an excess of the dehydrating system (Table 1, entry 1 ). Improved results could not be obtained despite attempting several optimization experiments (Table 1, entries 2-6). We speculate that a possible reason behind this lack of reactivity lay in the fact that the alkyl iodophosphates were unstable in the present reaction system and were inclined to undergo rapid conversion into the inactive form(s), which led to incomplete conversion of the substrate. We then turned to the combination of triphenylphosphine and iodine as the reagents. Fortunately, this combination was very efficient (Table 1 , entry 7 ). Interestingly, the dehydration of formamides promoted by triphenylphosphine and carbon tetrachloride $\left(\mathrm{CCl}_{4}\right)$ (halohydrocarbon solvent, $60^{\circ} \mathrm{C}, 2.5 \mathrm{~h}$ ) has been reported previously, ${ }^{10 \mathrm{c}}$ but there are no related studies on the use of triphenylphosphine and iodine, although the latter is faster and more convenient (see below).
We next examined the dehydration of $\mathrm{N}$-(4-bromophenyl)formamide (1) as a model system to optimize the reaction conditions. As shown in Table 2, the reactions in many of the common aprotic solvents, such as halohydrocarbons, ether and hydrocarbon, generated isonitrile $\mathbf{2 b}$ in good to excellent yields (Table 2, entries 2-6). However, when the dehydration was conducted in $\mathrm{N}, \mathrm{N}$-dimethylformamide, only a trace amount of the product was observed (Table 2 , entry 1). Among the tested solvents, dichloromethane gave the best performance (Table 2, entry 6). Therefore, dichloromethane was the solvent of choice for further investigations. Screening the base indicated that the dehydration reaction could be accomplished with common organic bases (Table 2, entries 6-11), but not with inorganic bases (Table 2 , entries 12-14). Among the tested common organic bases, tertiary amines such as triethylamine and $\mathrm{N}, \mathrm{N}$-diisopropylethylamine proved to be superior (Table 2, entries 6 and 7 vs $8-11$ ). Therefore, we established optimized conditions for the dehydration of formamides using the combination of triphenylphosphine and iodine for the preparation of isonitriles. The reaction was complete within one hour in dichloromethane using triphenylphosphine (1.5 equiv) and iodine (1.5 equiv) in the presence of triethylamine or $\mathrm{N}, \mathrm{N}$ diisopropylethylamine (3.0 equiv) at room temperature.

Under the optimized conditions, the substrate scope of our protocol was examined. The results, which are summarized in Scheme 1, demonstrate the generality of this method. A wide range of $N$-aryl- and $N$-alkyl-substituted formamides were quickly converted into the expected isonitriles in good to excellent yields. $\mathrm{N}$-Aryl-substituted substrates containing an electron-withdrawing or an electron-donating group on the benzene ring gave good results. Various functional groups, such as ether, halo, nitro, ester, and 
Table 2 Optimization of the Reaction Conditions for the Dehydration of $\mathrm{N}$-(4-Bromophenyl)formamide (1b) ${ }^{\text {a }}$

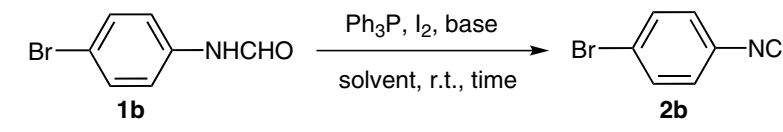

\begin{tabular}{lllll}
\hline Entry & Solvent & Base & Time & Yield \\
\hline 1 & DMF & $\mathrm{Et}_{3} \mathrm{~N}$ & $5 \mathrm{~h}$ & trace \\
$2^{\mathrm{c}}$ & $\mathrm{THF}$ & $\mathrm{Et}_{3} \mathrm{~N}$ & $5 \mathrm{~h}$ & $80 \%$ \\
$3^{\mathrm{c}}$ & $\mathrm{CHCl}_{3}$ & $\mathrm{Et}_{3} \mathrm{~N}$ & $5 \mathrm{~h}$ & $84 \%$ \\
4 & toluene & $\mathrm{Et}_{3} \mathrm{~N}$ & $8 \mathrm{~h}$ & $82 \%$ \\
5 & $\mathrm{DCE}$ & $\mathrm{Et}_{3} \mathrm{~N}$ & $1 \mathrm{~h}$ & $84 \%$ \\
6 & $\mathrm{CH}_{2} \mathrm{Cl}_{2}$ & $\mathrm{Et}_{3} \mathrm{~N}$ & $1 \mathrm{~h}$ & $90 \%$ \\
7 & $\mathrm{CH}_{2} \mathrm{Cl}_{2}$ & DIPEA & $1 \mathrm{~h}$ & $87 \%$ \\
8 & $\mathrm{CH}_{2} \mathrm{Cl}_{2}$ & DIPA & $1 \mathrm{~h}$ & $69 \%$ \\
9 & $\mathrm{CH}_{2} \mathrm{Cl}_{2}$ & $\mathrm{DBU}$ & $5 \mathrm{~h}$ & $56 \%$ \\
10 & $\mathrm{CH}_{2} \mathrm{Cl}_{2}$ & DABCO & $5 \mathrm{~h}$ & $52 \%$ \\
11 & $\mathrm{CH}_{2} \mathrm{Cl}_{2}$ & $\mathrm{DMAP}_{1}$ & $4 \mathrm{~h}$ & $60 \%$ \\
12 & $\mathrm{CH}_{2} \mathrm{Cl}_{2}$ & $\mathrm{KOH}_{12}$ & $5 \mathrm{~h}$ & no reaction \\
13 & $\mathrm{CH}_{2} \mathrm{Cl}_{2}$ & $\mathrm{~K}_{2} \mathrm{CO}_{3}$ & $5 \mathrm{~h}$ & no reaction \\
14 & $\mathrm{CH}_{2} \mathrm{Cl}_{2}$ & $\mathrm{Na}_{2} \mathrm{CO}_{3}$ & $5 \mathrm{~h}$ & no reaction \\
\hline
\end{tabular}

a Reaction conditions: $1 \mathbf{b}(1.0 \mathrm{mmol}), \mathrm{Ph}_{3} \mathrm{P}(1.5 \mathrm{mmol}), \mathrm{I}_{2}(1.5 \mathrm{mmol})$, base $(3.0 \mathrm{mmol})$, solvent $(3 \mathrm{~mL})$, r.t. (unless otherwise stated).

${ }^{\mathrm{b}}$ Yield of isolated product.

${ }^{C} \mathrm{Ph}_{3} \mathrm{P}(2.0 \mathrm{mmol}), \mathrm{I}_{2}(2.0 \mathrm{mmol})$ and $\mathrm{Et}_{3} \mathrm{~N}(4.0 \mathrm{mmol})$ were employed.

alkoxycarbonylamino, were only slightly affected under these conditions. The positional isomers of substituted $\mathrm{N}$ phenylformamides afforded the expected products in similar yields (Scheme $1, \mathbf{2 c}$ vs $\mathbf{2 i}$ and $\mathbf{2 j}$, and $\mathbf{2 g}$ vs $\mathbf{2 h}$ ). Other $\mathbf{o -}$ mono and 0,0 -disubstituted $N$-phenylformamides also gave good results (2k and $\mathbf{2 1}$ ), which indicated that steric effects adjacent to the formamido group did not significantly affect the progress of the reactions.

It should be noted that the dehydrations of both acidand alkali-sensitive substrates produced the expected isonitriles in good yields, without the side-chain protecting groups being affected ( $\mathbf{2 m}$ and $\mathbf{2 n}$ ). Due to the fact that most syntheses of isonitriles take place under alkaline conditions, related examples containing an alkali-sensitive group are rare. ${ }^{9}, 10 a$ Accordingly, Sureshbabu et al. reported that substrates containing an alkali-sensitive 9-fluorenylmethyloxycarbonylamino (FmocNH) moiety could be dehydrated using the Burgess reagent in dichloromethane at reflux temperature under neutral reaction conditions. ${ }^{10 a}$ They pointed out that the methods employing phosphorus(V) oxychloride/pyridine and triphenylphosphine/carbon tetrachloride did not produce satisfactory results. Compared with Sureshbabu's method, our protocol did not require an expensive water-sensitive reagent, or a heating device, since our reactions were conducted at room temperature

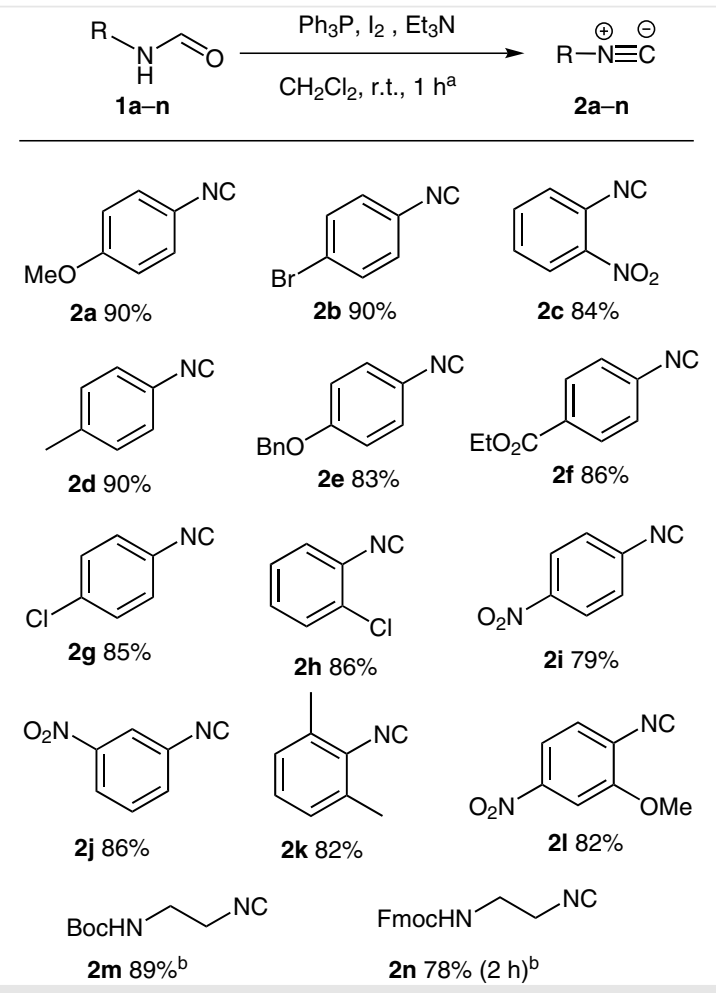

Scheme 1 Substrate scope for the preparation of isonitriles via the dehydration of formamides using the combination of triphenylphosphine and iodine. ${ }^{a}$ Reagents and conditions: 1 (1 mmol), $\mathrm{Ph}_{3} \mathrm{P}(1.5 \mathrm{mmol}), \mathrm{I}_{2}$ (1.5 mmol), $\mathrm{Et}_{3} \mathrm{~N}(3 \mathrm{mmol}), \mathrm{CH}_{2} \mathrm{Cl}_{2}(3 \mathrm{~mL})$, unless noted otherwise. The products were purified on silica gel. ${ }^{\mathrm{b}}$ Conditions as above, but with DIPEA ( $3 \mathrm{mmol}$ ) as the base instead of $\mathrm{Et}_{3} \mathrm{~N}$

and used reagents that were stable toward moisture. Moreover, the combined cost of triphenylphosphine and iodine is less than $10 \%$ that of the Burgess reagent, ${ }^{12}$ whereas the dehydrating efficiency of our approach was equivalent to that of Sureshbabu's method. In addition, Kitano's method for isonitrile synthesis gave good results with acid- and alkalisensitive substrates using chlorophosphate compounds as the dehydrating reagent, ${ }^{9}$ however, chlorophosphate compounds are not as stable as triphenylphosphine and iodine toward moisture, which is disadvantageous when storing reagents.

Gratifyingly, when analytical grade dichloromethane was employed (as received commercially), the reaction yields were of no significant difference. Moreover, purification of the products was very simple (column chromatography); even the purification of relatively highly polar $\mathbf{2 m}$ could be achieved easily using polar dichloromethane as the eluent. Removal of the triphenylphosphine oxide by-product from reactions which employ triphenylphosphine is often troublesome. However, in our case, all the target compounds were easily separated from polar triphenylphosphine oxide due to the fact that isocyanides are of relatively low polarity. 


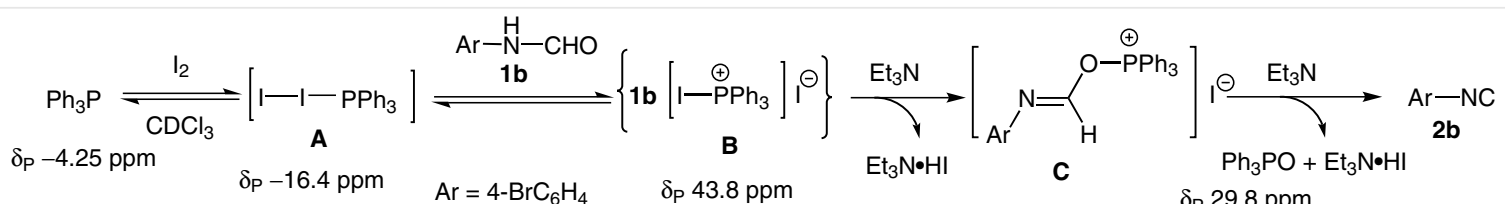

Scheme 2 Postulated pathway for the synthesis of an isonitrile mediated by triphenylphosphine

To establish the mechanism of the current process we used ${ }^{31} \mathrm{P}$ NMR spectroscopy to monitor the progress of the reaction. As shown in Scheme 2, the ${ }^{31} \mathrm{P}$ NMR signal of triphenylphosphine appeared at $\delta=-4.25$ in deuterochloroform. When an equimolar amount of iodine was added to the solution, a signal appeared at $\delta=-16.4$, which was due to the 'spoke' species A. ${ }^{13 a}$ When formamide $\mathbf{1 b}$ was introduced into the mixture, this signal was slightly shifted to $\delta=-14.0$, and a new minor signal appeared at $\delta=43.8$. Bricklebank et al. investigated the reaction of triphenylphosphine with iodine in detail in deuterochloroform; they revealed that the chemical shift of the ionic structure, $\left[\mathrm{Ph}_{3} \mathrm{PI}\right]^{+}$, appeared at $\delta=44.8$ and was mostly not affected by its counterions. ${ }^{13 \mathrm{~b}}$ Thus, we speculated that the signal at $\delta=43.8$ resulted from complex $B$ or from similar structures, in which the key structural feature was a $\left[\mathrm{Ph}_{3} \mathrm{PI}\right]^{+}$cation, and the addition of formamide $\mathbf{1}$ accelerated the ionization of the 'spoke' species $\mathbf{A}$ to form the ionic complex B. ${ }^{13 \mathrm{~b}, \mathrm{c}} \mathrm{Af}-$ ter triethylamine had been added, the signal at $\delta=-14.0$ shifted to $\delta=-16.5$, and that at $\delta=43.8$ quickly disappeared. At the same time, a new resonance appeared at $\delta=$ 29.8 , which was assigned to triphenylphosphine oxide. The addition of triethylamine gradually weakened the intensity of the signal at $\delta=-16.5$ and simultaneously led to an increase in the intensity of the signal at $\delta=29.8$. After five hours at room temperature, no further perceptible change was observed in the ${ }^{31} \mathrm{P}$ NMR spectrum. This observation was consistent with the consumption of formamide $\mathbf{1 b}$ along with the formation of isonitrile $\mathbf{2 b}$ and triphenylphosphine oxide, which was monitored by TLC. Thus, the formation of isonitrile $\mathbf{2 b}$ was presumed to occur via $\alpha$ elimination of a proton and triphenylphosphine oxide from intermediate phosphonium salt $\mathbf{C}$ with the aid of a base, similar to the triphenylphosphine/carbon tetrachloride mediated mechanism proposed by Appel et al. ${ }^{10 \mathrm{c}}$ Bae and coworkers investigated the synthesis of $O^{6}$-(benzotriazol-1yl)inosine nucleosides promoted by the reagent combination of triphenylphosphine and iodine. They proved that the signal due to the nucleoside phosphonium salt appeared at $\delta=66.2 .{ }^{13 \mathrm{~d}}$ However, the ${ }^{31} \mathrm{P}$ NMR spectroscopic signal of phosphonium salt intermediate $\mathbf{C}$ was not observed in our system, which is most possibly due to its low concentration.

In conclusion, the dehydration of various $\mathrm{N}$-substituted formamides with the reagent combination of triphenylphosphine and molecular iodine afforded smoothly the corresponding isocyanides in high yields. Electronic effects and steric hindrance resulting from substituents on the aromatic ring did not affect significantly the progress of these reactions. Both acid- and alkali-sensitive substrates produced the expected isonitriles in good yields without the sidechain protecting groups being affected. We believe that this method represents a mild, convenient, efficient and costeffective route to prepare various isocyanides.

Commercially available reagents were used as received. Formamides $\mathbf{1 a}, \mathbf{1 b}, \mathbf{1 d}, \mathbf{1 g}$ and $\mathbf{1 h}$ were prepared using the direct formic acid amidation method, ${ }^{14 a}$ formamides $\mathbf{1 c}$, $\mathbf{1 i}$ and $\mathbf{1 j}$ were obtained using $\mathrm{ZnO}-$ catalyzed formic acid amidation, ${ }^{14 \mathrm{~b}}$ formamides $\mathbf{1 e}, \mathbf{1 f}$ and $\mathbf{1 1}$ were synthesized via ethyl formate amidation, ${ }^{9}$ and formamide $\mathbf{1 k}$ was prepared using the mixed anhydride method. ${ }^{14 \mathrm{c}}$ Formamides $\mathbf{1 m}$ and $\mathbf{1 n}$ were prepared according to the literature. ${ }^{14 \mathrm{~d}}$ All solvents for chromatographic separations were distilled before use. Petroleum ether (PE) refers to the fraction boiling in the $60-90{ }^{\circ} \mathrm{C}$ range. Column chromatography was carried out using Haiyang 200-300 mesh silica gel (Qingdao, China). FT-IR spectra (wavelength range $=4000-400 \mathrm{~cm}^{-1}$ ) were obtained using a Bruker TENSOR-27 FT-IR Spectrometer (Bruker). Samples were prepared as $\mathrm{KBr}$ pellets. ${ }^{1} \mathrm{H}$ and ${ }^{13} \mathrm{C}$ NMR spectra were recorded on Bruker $300 \mathrm{MHz}$ or $600 \mathrm{MHz}$ spectrometers at $293 \mathrm{~K}$. Chemical shifts $(\delta)$ were internally referenced to the residual solvent signals $\left(\mathrm{CDCl}_{3}\right.$ at $7.26 \mathrm{ppm}$ for ${ }^{1} \mathrm{H}$, and at $77.00 \mathrm{ppm}$ for $\left.{ }^{13} \mathrm{C}\right)$ relative to tetramethylsilane. Data are reported as follows: multiplicity $(\mathrm{s}=$ singlet, $\mathrm{d}=$ doublet, $\mathrm{t}=$ triplet, $\mathrm{q}=$ quartet, $\mathrm{m}=$ multiplet, $\mathrm{br}=$ broad, br s = broad singlet), coupling constant(s) (Hz), integration. The structures of all the known products were confirmed by comparison with the spectroscopic data of authentic samples. The yields in Table 2 and Scheme 1 refer to those of isolated products (average of two runs).

\section{Isocyanides 2; General Procedure}

To a stirred solution of formamide $\mathbf{1}(1.0 \mathrm{mmol})$ and $\mathrm{I}_{2}(381 \mathrm{mg}, 1.5$ $\mathrm{mmol}$ ) in $\mathrm{CH}_{2} \mathrm{Cl}_{2}$ (3 mL) was added $\mathrm{Ph}_{3} \mathrm{P}$ (394 mg, $1.5 \mathrm{mmol}$ ), followed by the dropwise addition of $\mathrm{Et}_{3} \mathrm{~N}(415 \mu \mathrm{L}, 301 \mathrm{mg}, 3 \mathrm{mmol})$. The mixture was stirred at r.t. until the consumption of the formamide was complete (TLC monitoring, typically $1 \mathrm{~h}$ ), and then diluted with $\mathrm{CH}_{2} \mathrm{Cl}_{2}(10 \mathrm{~mL})$ and washed with ice-cold sat. aq $\mathrm{Na}_{2} \mathrm{~S}_{2} \mathrm{O}_{3}$ solution (10 $\mathrm{mL})$. The aq phase was extracted with $\mathrm{CH}_{2} \mathrm{Cl}_{2}(2 \times 10 \mathrm{~mL})$. Each portion of the organic phase was sequentially washed with deionized $\mathrm{H}_{2} \mathrm{O}(10 \mathrm{~mL})$ and brine $(10 \mathrm{~mL})$, dried over anhydrous $\mathrm{Na}_{2} \mathrm{SO}_{4}$, and filtered. The combined organic phase was concentrated under reduced pressure and purified by column chromatography (silica gel, typically $\mathrm{PE}$ as the eluent) to give the corresponding isocyanide $\mathbf{2}$. Any deviations from this procedure are noted in Table 2 and Scheme 1.

\section{4-Methoxyphenyl Isocyanide (2a) $)^{10 \mathrm{~b}}$}

Yield: $119 \mathrm{mg}$ (90\%); brown oil.

IR (KBr): $2125(\mathrm{~s}) \mathrm{cm}^{-1}$. 
${ }^{1} \mathrm{H}$ NMR $\left(300 \mathrm{MHz}, \mathrm{CDCl}_{3}\right): \delta=7.19(\mathrm{~d}, J=8.7 \mathrm{~Hz}, 2 \mathrm{H}), 6.78(\mathrm{~d}, J=8.9$ $\mathrm{Hz}, 2 \mathrm{H}), 3.72$ (s, $3 \mathrm{H})$.

${ }^{13} \mathrm{C} \mathrm{NMR}\left(75 \mathrm{MHz}, \mathrm{CDCl}_{3}\right): \delta=162.4(\mathrm{t}, J=5.8 \mathrm{~Hz}), 159.4,127.2,118.8$ $(\mathrm{t}, J=14.9 \mathrm{~Hz}), 114.1,55.1$.

\section{4-Bromophenyl Isocyanide (2b) $)^{15 a}$}

Yield: $164 \mathrm{mg}$ (90\%); white amorphous solid.

IR (KBr): $2125(\mathrm{~m}) \mathrm{cm}^{-1}$.

${ }^{1} \mathrm{H} \mathrm{NMR} \mathrm{(300} \mathrm{MHz,} \mathrm{CDCl}_{3}$ ): $\delta=7.53(\mathrm{~d}, J=8.6 \mathrm{~Hz}, 2 \mathrm{H}), 7.25$ (d, $J=8.4$ $\mathrm{Hz}, 2 \mathrm{H})$.

${ }^{13} \mathrm{C} \mathrm{NMR}\left(75 \mathrm{MHz}, \mathrm{CDCl}_{3}\right): \delta=165.8(\mathrm{t}, J=6.2 \mathrm{~Hz}), 132.6,127.8,125.4$ ( $\mathrm{t}, J=13.8 \mathrm{~Hz}), 123.3$.

\section{2-Nitrophenyl Isocyanide (2c) ${ }^{15 b}$}

Yield: $124 \mathrm{mg}$ (84\%); yellow amorphous solid.

IR (KBr): $2125(\mathrm{w}) \mathrm{cm}^{-1}$.

${ }^{1} \mathrm{H}$ NMR $\left(300 \mathrm{MHz}, \mathrm{CDCl}_{3}\right): \delta=8.11(\mathrm{dd}, J=1.4 \mathrm{~Hz}, 8.2 \mathrm{~Hz}, 1 \mathrm{H}), 7.73$ (dt, $J=1.3 \mathrm{~Hz}, 7.7 \mathrm{~Hz}, 1 \mathrm{H}), 7.67-7.57(\mathrm{~m}, 2 \mathrm{H})$.

${ }^{13} \mathrm{C}$ NMR (75 MHz, $\mathrm{CDCl}_{3}$ ): $\delta=173.8$ (br), 144.1 (br), 134.2, 130.1, $129.8,125.5,120.9(\mathrm{t}, J=16.9 \mathrm{~Hz})$.

\section{4-Methylphenyl Isocyanide (2d) ${ }^{15 c}$}

Yield: $105 \mathrm{mg}$ (90\%); brown oil.

IR (KBr): 2125 (s) $\mathrm{cm}^{-1}$.

${ }^{1} \mathrm{H} \mathrm{NMR}\left(600 \mathrm{MHz}, \mathrm{CDCl}_{3}\right): \delta=7.25(\mathrm{~d}, J=8.2 \mathrm{~Hz}, 2 \mathrm{H}), 7.17(\mathrm{~d}, J=8.2$ $\mathrm{Hz}, 2 \mathrm{H}), 2.37$ (s, $3 \mathrm{H})$.

${ }^{13} \mathrm{C}$ NMR $\left(151 \mathrm{MHz}, \mathrm{CDCl}_{3}\right): \delta=163.5(\mathrm{t}, J=5.6 \mathrm{~Hz}), 139.6,129.9$, $126.1,124.1(\mathrm{t}, J=13.5 \mathrm{~Hz}), 21.2$.

\section{4-Benzyloxyphenyl Isocyanide (2e) ${ }^{9}$}

Yield: $174 \mathrm{mg}$ (83\%); pale yellow amorphous solid.

IR (KBr): 2125 (s) $\mathrm{cm}^{-1}$.

${ }^{1} \mathrm{H} \mathrm{NMR}\left(600 \mathrm{MHz}, \mathrm{CDCl}_{3}\right): \delta=7.45-7.38(\mathrm{~m}, 4 \mathrm{H}), 7.38-7.33(\mathrm{~m}, 1 \mathrm{H})$, 7.31 (d, $J=8.9 \mathrm{~Hz}, 2 \mathrm{H}), 6.94$ (dt, $J=8.9 \mathrm{~Hz}, 2.6 \mathrm{~Hz}, 2 \mathrm{H}), 5.08$ (s, $2 \mathrm{H}$ ).

${ }^{13} \mathrm{C}$ NMR (150.9 MHz, $\left.\mathrm{CDCl}_{3}\right): \delta=163.0$ (br), 159.0, 136.1, 128.7, $128.3,127.7,127.4,119.8(\mathrm{t}, J=13.4 \mathrm{~Hz}), 115.5,70.4$.

\section{Ethyl 4-Isocyanobenzoate (2f) ${ }^{15 a}$}

Yield: $151 \mathrm{mg}$ (86\%); pale brown amorphous solid.

IR (KBr): 2128 (s) $\mathrm{cm}^{-1}$.

${ }^{1} \mathrm{H} \mathrm{NMR}\left(600 \mathrm{MHz}, \mathrm{CDCl}_{3}\right): \delta=8.07(\mathrm{dt}, J=8.7 \mathrm{~Hz}, 2.0 \mathrm{~Hz}, 2 \mathrm{H}), 7.43(\mathrm{~d}$, $J=8.6 \mathrm{~Hz}, 2 \mathrm{H}), 4.39$ (q, $J=7.1 \mathrm{~Hz}, 2 \mathrm{H}), 1.39(\mathrm{t}, J=7.1 \mathrm{~Hz}, 3 \mathrm{H})$.

${ }^{13} \mathrm{C}$ NMR $\left(151 \mathrm{MHz}, \mathrm{CDCl}_{3}\right): \delta=167.2(\mathrm{br}), 164.9,131.3,130.8,129.9$ $(\mathrm{t}, J=13.1 \mathrm{~Hz}), 126.4,61.5,14.2$.

\section{4-Chlorophenyl Isocyanide (2g) ${ }^{15 a}$}

Yield: $117 \mathrm{mg}$ (85\%); white solid.

IR (KBr): 2128 (s) $\mathrm{cm}^{-1}$.

${ }^{1} \mathrm{H}$ NMR (300 MHz, $\mathrm{CDCl}_{3}$ ): $\delta=7.41-7.26(\mathrm{~m}, 4 \mathrm{H})$.

${ }^{13} \mathrm{C}$ NMR (75 MHz, $\mathrm{CDCl}_{3}$ ): $\delta=165.4$ (br), 135.2, 129.6, 127.5, $124.8(\mathrm{t}$, $J=13.3 \mathrm{~Hz}$ ).

2-Chlorophenyl Isocyanide (2h) ${ }^{15 d}$

Yield: $118 \mathrm{mg}$ (86\%); white solid.
${ }^{1} \mathrm{H}$ NMR $\left(300 \mathrm{MHz}, \mathrm{CDCl}_{3}\right): \delta=7.47(\mathrm{dd}, J=7.9 \mathrm{~Hz}, 1.3 \mathrm{~Hz}, 1 \mathrm{H}), 7.42$ (dd, $J=7.6 \mathrm{~Hz}, 1.3 \mathrm{~Hz}, 1 \mathrm{H}$ ), 7.39-7.26 (m, $2 \mathrm{H}$ ).

${ }^{13} \mathrm{C} \mathrm{NMR}\left(75 \mathrm{MHz}, \mathrm{CDCl}_{3}\right): \delta=168.9(\mathrm{br}), 130.6,130.2,130.0,127.8$, $127.4,125.3(\mathrm{t}, J=15.4 \mathrm{~Hz})$.

\section{4-Nitrophenyl Isocyanide (2i) ${ }^{10 b}$}

Yield: $117 \mathrm{mg}$ (79\%); white amorphous solid.

IR (KBr): $2130(\mathrm{~s}) \mathrm{cm}^{-1}$.

${ }^{1} \mathrm{H} \mathrm{NMR}\left(300 \mathrm{MHz}, \mathrm{CDCl}_{3}\right): \delta=8.29(\mathrm{~d}, J=8.9 \mathrm{~Hz}, 2 \mathrm{H}), 7.58(\mathrm{~d}, J=8.8$ $\mathrm{Hz}, 2 \mathrm{H})$.

${ }^{13} \mathrm{C} \mathrm{NMR}\left(151 \mathrm{MHz}, \mathrm{CDCl}_{3}\right): \delta=170.0(\mathrm{br}), 147.6,131.3(\mathrm{t}, J=12.0 \mathrm{~Hz})$, 127.5, 125.0.

\section{3-Nitrophenyl Isocyanide (2j) ${ }^{15 \mathrm{~d}}$}

Yield: $127 \mathrm{mg}$ (86\%); white amorphous solid.

IR (KBr): $2142(\mathrm{~m}) \mathrm{cm}^{-1}$.

${ }^{1} \mathrm{H}$ NMR $\left(300 \mathrm{MHz}, \mathrm{CDCl}_{3}\right): \delta=8.28(\mathrm{~d}, J=8.1 \mathrm{~Hz}, 1 \mathrm{H}), 8.22(\mathrm{~s}, 1 \mathrm{H})$, $7.74(\mathrm{~d}, J=8.0 \mathrm{~Hz}, 1 \mathrm{H}), 7.66(\mathrm{t}, J=8.0 \mathrm{~Hz}, 1 \mathrm{H})$.

${ }^{13} \mathrm{C} \mathrm{NMR}\left(75 \mathrm{MHz}, \mathrm{CDCl}_{3}\right): \delta=167.6(\mathrm{br}), 148.2,132.1,130.6,127.1(\mathrm{t}$, $J=11.9 \mathrm{~Hz}), 124.1,121.5$.

\section{2,6-Dimethylphenyl Isocyanide (2k) $)^{14 c}$}

Yield: $108 \mathrm{mg}$ (82\%); white amorphous solid.

IR (KBr): $2122(\mathrm{~s}) \mathrm{cm}^{-1}$.

${ }^{1} \mathrm{H} \mathrm{NMR}\left(600 \mathrm{MHz}, \mathrm{CDCl}_{3}\right): \delta=7.18(\mathrm{t}, J=7.6 \mathrm{~Hz}, 1 \mathrm{H}), 7.09$ (d, $J=7.6$ $\mathrm{Hz}, 2 \mathrm{H}), 2.42$ (s, $6 \mathrm{H})$.

${ }^{13} \mathrm{C}$ NMR (151 MHz, $\left.\mathrm{CDCl}_{3}\right): \delta=167.8$ (br), 134.8, 128.6, 127.7, 126.7 $(\mathrm{t}, J=12.9 \mathrm{~Hz}), 18.8$.

\section{2-Methoxy-4-nitrophenyl Isocyanide (21) ${ }^{9}$}

Yield: $146 \mathrm{mg}$ (82\%); light yellow amorphous solid.

${ }^{1} \mathrm{H}$ NMR $\left(300 \mathrm{MHz}, \mathrm{CDCl}_{3}\right.$ ): $\delta=7.86(\mathrm{dd}, J=8.9 \mathrm{~Hz}, 2.1 \mathrm{~Hz}, 1 \mathrm{H}), 7.84$ (br s, $1 \mathrm{H}), 7.51$ (d, $J=8.4 \mathrm{~Hz}, 1 \mathrm{H}), 4.05(\mathrm{~s}, 3 \mathrm{H})$.

${ }^{13} \mathrm{C} \mathrm{NMR}\left(151 \mathrm{MHz}, \mathrm{CDCl}_{3}\right.$ ): $\delta=173.0$ (br s), 155.5, 148.4, 128.1, 121.1 $(\mathrm{t}, J=14.4 \mathrm{~Hz}), 115.8,107.1,56.8$.

\section{tert-Butyl (2-Isocyanoethyl)carbamate (2m) $)^{15 e}$}

The product was purified by column chromatography on silica gel [PE $\rightarrow$ PE-EtOAc, 80:20 (v/v)].

Yield: $151 \mathrm{mg}(89 \%)$; light yellow oil.

IR (KBr): $2150(\mathrm{~s}) \mathrm{cm}^{-1}$.

${ }^{1} \mathrm{H} \mathrm{NMR}\left(600 \mathrm{MHz}, \mathrm{CDCl}_{3}\right): \delta=5.15$ (s, $\left.1 \mathrm{H}\right), 3.49$ (br s, $\left.2 \mathrm{H}\right), 3.34$ (br s, $2 \mathrm{H}), 1.42$ (s, $9 \mathrm{H})$.

${ }^{13} \mathrm{C}$ NMR (151 MHz, $\left.\mathrm{CDCl}_{3}\right): \delta=157.4(\mathrm{br}), 155.6,80.0,41.9(\mathrm{t}, J=5.9$ $\mathrm{Hz}), 39.7,28.2$.

\section{(9H-Fluoren-9-yl)methyl (2-Isocyanoethyl)carbamate (2n) $)^{10 a}$}

The product was purified by column chromatography on silica gel $\left(\mathrm{PE} \rightarrow \mathrm{CH}_{2} \mathrm{Cl}_{2}\right)$.

Yield: $228 \mathrm{mg}$ (78\%); white amorphous solid.

IR (KBr): $2152(\mathrm{~m}) \mathrm{cm}^{-1}$.

${ }^{1} \mathrm{H}$ NMR $\left(600 \mathrm{MHz}, \mathrm{CDCl}_{3}\right): \delta=7.78(\mathrm{~d}, J=7.5 \mathrm{~Hz}, 2 \mathrm{H}), 7.59(\mathrm{~d}, J=7.4$ $\mathrm{Hz}, 2 \mathrm{H}), 7.41(\mathrm{t}, J=7.4 \mathrm{~Hz}, 2 \mathrm{H}), 7.33(\mathrm{t}, J=7.4 \mathrm{~Hz}, 2 \mathrm{H}), 5.42(\mathrm{~s}, 1 \mathrm{H})$, $4.44(\mathrm{~d}, J=6.8 \mathrm{~Hz}, 2 \mathrm{H}), 4.22(\mathrm{t}, J=6.8 \mathrm{~Hz}, 1 \mathrm{H}), 3.51(\mathrm{t}, J=4.6 \mathrm{~Hz}, 2 \mathrm{H})$, 3.44-3.39 (m, $2 \mathrm{H})$. 
${ }^{13} \mathrm{C}$ NMR $\left(151 \mathrm{MHz}, \mathrm{CDCl}_{3}\right): \delta=157.7(\mathrm{t}, J=11.3 \mathrm{~Hz}), 156.2,143.6$, 141.2, 127.7, 127.0, 124.9, 119.9, 66.9, 47.1, 41.7 (t, J = 5.3 Hz), 40.1.

\section{Acknowledgment}

The authors thank the National Natural Science Foundation of China (No. 20971105) and the Fundamental Research Funds for the Central Universities (XDJK2012B011) for financial support.

\section{Supporting Information}

Supporting information for this article is available online at http://dx.doi.org/10.1055/s-0034-1379111.

\section{References}

(1) (a) Tobisu, M.; Chatani, N. Chem. Lett. 2011, 40, 330. (b) Lang, S. Chem. Soc. Rev. 2013, 42, 4867.

(2) (a) Dömling, A. Chem. Rev. 2006, 106, 17. (b) El Kaim, L.; Grimaud, L. Tetrahedron 2009, 65, 2153. (c) Fei, X.-D.; Ge, Z.-Y.; Tang, T.; Zhu, Y.-M.; Ji, S.-J. J. Org. Chem. 2012, 77, 10321. (d) Vlaar, T.; Ruijter, E.; Znabet, A.; Janssen, E.; de Kanter, F. J. J.; Maes, B. U. W.; Orru, R. V. A. Org. Lett. 2011, 13, 6496. (e) Liu, B.; Yin, M.; Gao, H.; Wu, W.; Jiang, H. J. Org. Chem. 2013, 78, 3009. (f) Geden, J. V.; Pancholi, A. K.; Shipman, M. J. Org. Chem. 2013, 78, 4158. (g) Suginome, M.; Ito, Y. Adv. Polym. Sci. 2004, 171, 77.

(3) (a) Wilson, R. M.; Stockdill, J. L.; Wu, X.; Li, X.; Vadola, P. A.; Park, P. K.; Wang, P.; Danishefsky, S. J. Angew. Chem. Int. Ed. 2012, 51, 2834. (b) Lygin, A. V.; de Meijere, A. Angew. Chem. Int. Ed. 2010, 49, 9094. (c) Gulevich, A. V.; Zhdanko, A. G.; Orru, R. V. A.; Nenajdenko, V. G. Chem. Rev. 2010, 110, 5235.

(4) Pirrung, M. C.; Ghorai, S. J. Am. Chem. Soc. 2006, 128, 11772.

(5) (a) Ugi, I.; Fetzer, U.; Eholzer, U.; Knupfer, H.; Offermann, K. Angew. Chem., Int. Ed. Engl. 1965, 4, 472. (b) Weber, W. P.; Gokel, G. W.; Ugi, I. K. Angew. Chem., Int. Ed. Engl. 1972, 11, 530.
(6) Obrecht, R.; Herrmann, R.; Ugi, I. Synthesis 1985, 400.

(7) Karl, R.; Lemmen, P.; Ugi, I. Synthesis 1989, 718.

(8) For example, $\mathrm{POCl}_{3}$ is included in the List of Hazardous Chemicals issued by the Chinese State Administration of Work Safety as well as the Highly Toxic Chemicals Directory jointly issued by eight ministries of the Chinese Government.

(9) Kobayashi, G.; Saito, T.; Kitano, Y. Synthesis 2011, 3225.

(10) (a) Sureshbabu, V. V.; Narendra, N.; Nagendra, G. J. Org. Chem. 2009, 74, 153. (b) Porcheddu, A.; Giacomelli, G.; Salaris, M. J. Org. Chem. 2005, 70, 2361. (c) Appel, R.; Kleinstück, R.; Ziehn, K.-D. Angew. Chem., Int. Ed. Engl. 1971, 10, 132.

(11) Luo, Q.-L.; Lv, L.; Li, Y.; Tan, J.-P.; Nan, W.; Hui, Q. Eur. J. Org. Chem. 2011, 6916.

(12) Price ratios are based on the amount of $25 \mathrm{~g}$ from the current J\&K Scientific Catalog in China, calculated from the price per mole of each reagent. Price ratios calculated from other commercial chemicals catalogs were similar.

(13) (a) Godfrey, S. M.; Kelly, D. G.; McAuliffe, C. A.; Mackie, A. G.; Pritchard, R. G.; Watson, S. M. J. Chem. Soc., Chem. Commun. 1991, 1163. (b) Bricklebank, N.; Godfrey, S. M.; Mackie, A. G.; McAuliffe, C. A.; Pritchard, R. G.; Kobryn, P. J. J. Chem. Soc., Dalton Trans. 1993, 101. (c) Núñez, R.; Farràs, P.; Teixidor, F.; Viñas, C.; Sillanpää, R.; Kivekäs, R. Angew. Chem. Int. Ed. 2006, 45, 1270; and references therein. (d) Bae, S.; Lakshman, M. K. J. Org. Chem. 2008, 73, 1311.

(14) (a) Bandgar, B. P.; Kinkar, S. N.; Chobe, S. S.; Mandawad, G. G.; Yemul, O. S.; Dawane, B. S. Arch. Appl. Sci. Res. 2011, 3, 246. (b) Hosseini-Sarvari, M.; Sharghi, H. J. Org. Chem. 2006, 71, 6652. (c) Nanjo, T.; Tsukano, C.; Takemoto, Y. Org. Lett. 2012, 14, 4270. (d) Wang, W.-h.; Zhang, T.; Xu, P. J. Chin. Pharm. Sci. 2003, $12,66$.

(15) (a) Guirado, A.; Zapata, A.; Gómez, J. L.; Trabalón, L.; Gálvez, J. Tetrahedron 1999, 55, 9631. (b) Hahn, F. E.; Plumed, C. G.; Münder, M.; Lügger, T. Chem. Eur. J. 2004, 10, 6285. (c) Polisar, J. G.; Norton, J. R. Tetrahedron 2012, 68, 10236. (d) Ugi, I.; Meyr, R. Chem. Ber. 1960, 93, 239. (e) Zhang, T.; Xu, P. Chin. J. Med. Chem. 2002, 16, 325. 